\title{
Perceptions of In-service EFL Teachers about Their Pre-service Practicum Experience in Iraqi-Kurdistan
}

\author{
Nawzar M. Haji ${ }^{1}$ \\ ${ }^{1}$ Tishk International University, Erbil, Iraq \\ Correspondence: Nawzar M. Haji, Tishk International University, Erbil, Iraq. \\ E-mail: nawzar.haji@ishik.edu.iq
}

Received: April 7, 2019

Accepted: May 24, 2019

Online Published: June 1, 2019

doi: 10.23918/ijsses.v5i4p193

\begin{abstract}
Practicum is an integral part in most of the language teacher education (LTE) programs around the world. In many of these programs, practicum is designed to help student teachers put the theories they have learned into practice and get the chance to become familiar with the real world of teaching. Research has shown that there is a positive and strong relationship between teachers' sense of preparedness and the quality and longitude of the practicum they have taken in their pre-service preparation (Kee, 2012). This study investigated the perceptions of in-service EFL teachers about their pre-service practicum experience and its relation to their sense of preparedness in Iraqi-Kurdistan. A qualitative research method was used to reveal EFL teachers' feelings and attitudes towards their practicum experience. Interviews and side documents were used as tools for the collection of the data. The findings revealed that the majority of the participants were not satisfied with their practicum and described it as short, poorly organized, impractical, and insufficient.
\end{abstract}

Keywords: Practicum, EFL Teacher, In-Service, Pre-Service, Iraqi-Kurdistan

\section{Introduction}

K-12 (Kindergarten to $12^{\text {th }}$ grade) students in Iraqi-Kurdistan spend 12 years in schools taking English as a Foreign Language (EFL) classes, and yet their English proficiency levels are insufficient upon graduation (RAND 2012, Sofi-Karim 2015). It has been hypothesized that part of this issue goes back to the way EFL teachers have been prepared during their pre-service education programs. The scope of this study is devoted to the perceptions that EFL teachers hold regarding their practicum experience during their preservice preparation in the formal institutions charged with EFL teacher education in Iraqi- Kurdistan, a region of particular importance both to the researcher and to the world community.

\subsection{Significance of the Study}

Unfortunately, due to political, educational and administrative issues in Kurdistan, there is little research on the quality of EFL teacher education. There is little data available to inform us about Kurdish EFL teachers' perceptions about their pre-service preparation in general and practicum experience in particular. The lack of consistent knowledge on the topic of the role of practicum in EFL teacher education adds to the importance of this study. Therefore, this research attempted to explore this issue from the perspective of EFL teachers in Kurdistan. The results could impact the restructuring and reorganizing of the curriculum and instruction of the practicum in the institutions in charge of EFL teacher preparation in Kurdistan. 
Furthermore, the results of this study can offer a profound understanding of the EFL teachers' sense of preparedness and the ways they have been prepared. It examined their feelings, experiences and concerns about the overall process of their practicum and can therefore help policy makers, educational leaders and EFL teacher educators make positive changes according to these findings.

\subsection{Purpose of the Study}

The purpose of this study was to answer this question "What do in-service EFL teachers in Iraqi-Kurdistan say they think about the quality and length of the practicum during their teacher education? To do so, this study investigated the perceptions of in-service EFL teachers about their practicum experience during their pre-service teacher education programs.

\subsection{Research Questions}

This research addressed the following questions:

1. What do in-service EFL teachers in Iraqi-Kurdistan say they think about the quality and length of the practicum during their teacher education?

2. What do in-service EFL teachers in Iraqi-Kurdistan say they think about the quality of the feedback they received from their supervisors and cooperating teachers during the practicum?

\section{Literature Review}

\subsection{The Nature and Quality of Field Experience (Practicum)}

Field experience, usually referred to as practicum or teaching experience, is considered as one of the cornerstones of teacher preparation programs, and if not done adequately it can result in under prepared teachers (Darling-Hammond \& Chung, 2002; Darling-Hammond \& Bransford, 2005; Ingersol et al., 2007; Kee, 2011). Ingersol et al. (2007) stated that "the problem of low-quality teaching can be traced to inadequate and insufficient pre-employment training" (p. 1). Research has shown that there is a positive and strong relationship between teachers' sense of preparedness and the quality and longitude of the practicum they have taken in their pre-service preparation. Kee (2012) found that teachers who participated in a year-long practicum felt more prepared to teach than those who did not. Darling-Hammond \& Bransford (2005) assert that those student teachers who had field experiences early in their programs performed better as teachers. They believe that insufficient fieldwork is one of the major issues in teacher education programs that cause under-prepared teachers. "Fieldwork has often been divorced from coursework, inadequately designed, and placements have often failed to reflect standards for good teaching" (p. 454). Darling-Hammond and Chung concluded that "more systematic and connected clinical experience" (2002, p. 287) is a key to better teacher preparation. Like Kee, they suggest that a one-year long field experience can prepare teachers well if it is done with attention and consistent supervision from teacher educators and cooperating teachers. Sofi-Karim (2015) found the same thing in Kurdistan. He believes that insufficient and impractical student teacher practice in real classroom settings is one of the most important reasons behind teacher's sense of unpreparedness. He also found that the practicum period is too short, is poorly designed and is poorly followed up by the faculty supervisors and the cooperating teachers. Vernez et al. (2014) found that Kurdish prospective teachers are not involved in any clinical experience until late in their programs. 
The philosophical perception of different teacher preparation programs towards the practicum is a key point to understanding the objectives and components of it. Some programs look at the practicum as an opportunity to develop certain qualities and skills in novice teachers and help them for the real classrooms (Richards, 1987). The perspective of such programs towards the teacher preparation is more of a training in which they try to implement and develop certain skills in novice teachers. On the other hand, some other programs look at the process of practicum from a developmental perspective in which novice teachers find the opportunity to apply theory into practice, make mistakes, ask questions, investigate and develop their teaching abilities and skills through the process. The general philosophy of such programs is to increase the learning awareness of the teachers and help them to become life-long learners (Darling-Hammond \& Bransford, 2005). Therefore, the practicum and its objectives are very much under the influence of the general philosophy of the teacher education programs towards the objectives of teacher preparation (Richards \& Crookes, 1988). Practicum in Kurdistan is affected by the general philosophy of teacher education that emphasizes on training rather than education (Sofi-Karim, 2015; Vernez et al., 2014).

In teacher education programs' practicum, constructive post observation discussions and collaboration among student teachers, supervisors and cooperating teachers are crucial in raising student teachers' awareness. He (2009) stated, "without adequate communication between mentors and pre-service teachers regarding teaching expectations and beliefs, pre-service teachers leave the teacher education programs illprepared to negotiate potential conflict between their beliefs and reality of teaching, leading to dissonance and resistance to adaptation" (p. 264). Freeman (1991) explains that the practicum should foster a relationship between teacher educators and student teachers in a way to help the prospective teachers by providing them with insights and inputs to improve their teaching. The teacher educator's responsibility is to help the student teachers teach more effectively, but this cannot happen when the student teachers are not supervised and supported appropriately during their practice teaching.

In the context of Kurdistan, Iraq and the wider region, supervisors expect student teachers to accept their "advice" as a prescription and preferred methodology to teach. There is often no constructive discussion after the observation and no room for meaningful feedback. Time is limited, and the student teachers are only supervised once during the eight weeks period of the practice teaching. This short visit has no constructive consequences and is only done for the sake of a grade that is supposed to evaluate the performance of the student teachers. Furthermore, this type of supervision increases the anxiety of the student teachers and will not lead to a process of awareness-raising or collaboration that is necessary to help them become continuous learners (Sofi-Karim, 2015; Vernez et al., 2014).

Yet another issue is the role and responsibilities of the cooperating teachers that is not defined anywhere in the system. The cooperating schools and teachers are chosen on the basis of availability. Cooperating teachers are largely passive in the process. They are not instructed and encouraged to supervise the classrooms of the student teachers, they do not discuss with them about their teaching and they do not give them feedback (Sofi-Karim, 2015; Vernez et al., 2014). Payant \& Murphy (2012) reported similar results in their study concerning the roles and responsibilities of the cooperating teachers in the practicum. In their study, the cooperating teachers complained that they did not know their exact duties as cooperating teachers. In other words, their responsibilities as cooperating teachers were "poorly defined" (p. 9) by the practicum instructors. 


\subsection{Practicum in Language Teacher Education}

Practicum is an integral part in most of the language teacher education (LTE) programs around the world. In many of these programs, practicum is designed to help the student teachers put the theories they have learned into practice and get the chance to become familiar with the real world of teaching (Canh, 2014; Farrell, 2007, 2008; Johnson, 1996; Palmer, 1995; Richards \& Crookes, 1988). This practice teaching is usually supervised and mentored by two groups of people, the faculty members or practicum instructors who regularly visit the schools and supervise student teachers and the cooperating teachers who work in the field schools and mentor the student teachers' daily activities (Crookes, 2003).

One of the first studies in LTE practicum was conducted by Richards and Crookes (1988) in which they investigated the objectives, implementation and effectiveness of practicum in 60 TESOL (Teaching English to Speakers of Other Languages) programs around the United States. They discovered that the objectives of the practicum courses in these programs are built on their philosophy towards LTE. Some of these programs look at teacher preparation like a training in which they teach a certain type of skills to the prospective teachers and help them practice and show mastery of these skills. Some other programs, however, look at the preparation of teachers in terms of education. In such programs teacher preparation is not defined in terms of mastering certain skills, but rather a life-long process of learning awareness (Darling-Hammond \& Bransford, 2005). In another study, Stoynoff (1999) describes a successful model of TESOL practicum in the U.S. In his description, he explains that the success of the program is because of meaningful collaboration among the three groups of people who are involved in the process, namely the student teachers, the cooperating teachers, and the faculty supervisors. Stoynoff argues that in this model the three groups need to meet regularly and work as a team to achieve good results. In a similar study done by Payant and Murphy (2012), the importance of teamwork and constant communication among student teachers, cooperating teachers, and faculty supervisors is one of the major findings.

Flowerdew (1999) analyzed the practicum of an EFL (English as a Foreign Language) teacher education program in Hong Kong. He found that the success of the program is due to its ability in dealing with the idealistic views of the student teachers about teaching and recognizing the realities of the classrooms. In other words, the program tries to make the practicum experience a real challenge in which students face real classroom difficulties. Canh (2014) conducted a study about these classroom realities and the idealistic views of student teachers, which he calls great expectations, in Vietnam. He found that these tensions that are caused by the student teachers' misconceptions of the real world of teaching affect their capabilities and attitudes towards teaching negatively.

In his case study of a student teacher in Singapore, Farrell (2007) studied the effect of critical reflection in EFL teacher education practicum. He realized that the meaningful cooperation between student teachers and faculty supervisors is a key factor in the practicum. Farrell argues that critical reflections and meaningful discussions between the student teachers and faculty supervisors increases the learningawareness of the prospective teachers and helps them improve their teaching abilities and get ready for the real world of teaching. Ongondo and Borg's (2011) findings about the influence of supervision on the practice of English language student teachers in Kenya support Farrell's conclusions. They argue that the supervisions are brief, and the feedback is poor. Therefore, not much real learning about teaching accrues. 
Furthermore, Payant and Murphy's (2012) study is one of rare studies about the roles and responsibilities of cooperating teachers in TESOL practicum from their own point of view. In their study, they found that cooperating teachers were not sure about their responsibilities as mentors. They did not have any guidelines to follow and that they had not been trained to be cooperating teachers. In addition, the findings of the study indicated that there was no meaningful communication between the cooperating teachers and the faculty supervisors that lead to a low-quality practicum experience. In another study done in an English language Teaching (ELT) preparation program in Singapore, Farrell (2008) investigated the perceptions of 60 student teachers about the roles and responsibilities of cooperating teachers during the practicum. Farrell stated that most of the participants complained about the poor collaboration and feedback of the cooperating teachers and that they were not instructed and trained to be cooperating teachers. The same findings are reported by Sofi-Karim (2015) in his study of English language education in Kurdistan. He argued that the lack of collaboration between the cooperating teachers and faculty members affected the EFL teacher education practicum negatively, and that the cooperating teachers are not informed and instructed about their responsibilities in the process.

\section{Research Design}

\subsection{Nature of the Study}

I decided to employ a qualitative approach to examine the issue under investigation for three reasons. First, I believe that human subjects can be best studied by qualitative means. I found the qualitative study a place where I can hear the voices of the participants and approach the problem through their perspectives and understanding of the problem. Merriam and Tisdell state that "In fact, we believe that research focused on discovery, insight, and understanding from the perspectives of those being studied offers the greatest promise of making a difference in people's lives" $(2016$, p. 1). I conducted this research through EFL teachers' perspectives because their experiences and points of view about their preparation process are marginalized. They are seldom listened to and are neglected in the process of decision-making about their preparation that is particularly related to them (Sofi-Karim, 2015; Vernez et al., 2014). The second reason for choosing a qualitative methodology for conducting this study is that this type of study can show a whole picture of the problem that is referred to as a holistic account by Creswell. He stated, "Qualitative researchers try to develop a complex picture of the problem or issue under study. This involves reporting multiple perspectives, identifying the many factors involved in a situation, and generally sketching the larger picture that emerges" (2007, p. 39). Third, the study is descriptive. I have presented the findings in

the form of richly descriptive data. However, I have also used a survey for the purpose of triangulation and getting a more comprehensive perspective on the nature of the problem.

\subsection{Data Collection}

Data was collected by using two instruments: in-depth interviews, and document analysis. First, 20 EFL teachers who have graduated from the EFL teacher education program under study were interviewed. Second, the curriculum of the EFL teacher education program and some other related documents such as practicum guidelines and forms were analyzed. In-depth semi-structured interviews were the main source of data collection through this study. There are some very critical hidden sources of information for a qualitative researcher that cannot be observed. Because they cannot be observed by the researcher, feelings, opinions, and experiences of the people who are participating in a study like this are of utmost 
importance. Interviews help qualitative researchers to uncover these feelings and enter into the world of the participants and see the world through their eyes and understanding (Patton, 2015). Another reason for interviews is to reveal something that happened in the past, something that cannot be observed anymore. "Sometimes you want to know about something that happened in the past. Certainly, you cannot observe it therefore you need to interview someone who had been experienced that event" (Merriam \& Tisdell, 2016, p. 104). A semi-structured type of interview was conducted to help the researcher to be both systematic and flexible at the same time.

\subsection{Participants}

The target population of this study was English as a Foreign Language teachers who have graduated from the largest university in the Iraqi-Kurdistan region charged with teacher education. The EFL teacher preparation department of this University was the case under investigation for this study. This university follows the central system and policy administered by the KRG's Ministry of Higher Education and Scientific Research. All EFL teachers who have graduated from the governmental colleges of education and basic education/English Departments around the Kurdistan Region have experienced nearly identical systems and undergone the same training procedures during their undergraduate studies. Therefore, all the EFL teacher graduates of this university qualify for this study.

A convenience sampling strategy, based on teachers' willingness to participate, was conducted to gather data. This researcher made a Facebook group of EFL teachers in Kurdistan to facilitate the process of sampling and data collection. The group has about four hundred members who are all EFL teachers in basic and high schools around Kurdistan Region and have graduated from the teacher education program under investigation. A request of participation in the study, explaining all the requirements and rights was sent to all the group members. 380 members of this group agreed to participate in the study. Next, a sample of twenty EFL teachers were chosen from the people who accepted to participate in the study for the indepth interviews.

\section{Results}

\subsection{The Role of the Supervisors (Organization of Supervision)}

Each of the student teachers who participated in the study was observed only one time during the entire period of the practice teaching. Most of the participants believed that their supervisors were not helpful during the practicum. They complained about the infrequency of their supervisors' visits, the superficiality of the supervision process, the behavior of the supervisors, and the unhelpful feedback they received from their supervisors.

Interview Findings:

The participants argued that their supervisors visited them only one time and that was not sufficient. Mina said, "My supervisor came to the school only one time without giving me any feedback. It was just a waste of time." Chnar had the same experience. She was concerned about the infrequency of her supervisor's visit and poor evaluation. She said: 
My supervisor visited me only one time during the whole 40-day period of my practice teaching. I do not know how he could evaluate my teaching properly in one short visit. I tried to do my best and I was very nervous. I wish he could visit me two or more times so that I could show the best of my teaching.

Maher had the same opinion about the frequency of his supervisor's visit.

She only visited me once and scarcely gave me any advice regarding what I was doing. We talked for five minutes after the class. The supervisor could sit in the classroom more than one session, give critical and constructive feedback, and feel more responsible toward the student teachers.

The participants confirmed that they had a lot of stress because they knew that there was only one chance to demonstrate their abilities. They had to show the supervisors all they were capable of as an EFL teacher in 45 minutes and these time constraints caused them a lot of frustration. Mina stated, "It was one of the worst days of my life. I was scared because I could not concentrate on my thoughts." The participants explained that their stress affected their teaching negatively. Bayar added, "I had a lot of stress. This stress affected my performance negatively. I could do better if I did not have much stress."

The behavior of the supervisors was a concern mentioned by many of the participants. During the interviews, 17 out of 20 of them acknowledged that they saw rude behavior from their supervisors. Amin explained the situation as follows:

When I started my practice teaching in the school, I began to feel that I am a real teacher. Everything was so exciting. The day my supervisor came to visit me in the school, I was very well prepared to surprise him with my unique style of teaching. However, he did not like it and told me to stick to the traditional method. From that day, I fear to try any new methods.

Bayar, another EFL teacher, complained about the irresponsible behavior of the supervisor. He stated:

Well, I am sorry to say this, but my supervisor was very rude. During the class, I did not feel safe and I had a lot of stress. I remember I mispronounced a word and the supervisor corrected me in front of the students. I felt very embarrassed. He could have told me about my mistake after the class.

The participants argued that when they began the practice teaching in real classrooms, they expected the supervisors to respect them and treat them like real teachers and not like students. Indeed, most of the participants reported that the misbehavior of their supervisors affected their perspective toward teaching negatively.

This study also found that the supervisors' time constraints and busy schedules of supervising many student teachers proved to be a big issue. Some of the participants talked about the limited time of the supervisors and their rush after the class. Mina complained:

After the class finished, I was excited to hear from my supervisor about how I did. I felt very disappointed when he said that he could not talk to me because he needed to go to another 
school and attend another student teacher's class. I was expecting him to give me some feedback and the ways I could improve myself.

In accordance to Mina, Armeen also stated:

I talked to my supervisor only once during my practice teaching. That was absolutely neither enough nor helpful because all I got was the grade of my practice teaching. He did not give me any evaluation or instructions so that I could learn about my week and strong points and improve my teaching.

Furthermore, most of the participants were concerned about the professionalism of the supervisors. Interviews with all the participants revealed this lack of supervisors' professionalism. They argued that the supervisors did not know what to do inside the classroom. The participants believed that their supervisors were not familiar with the very basic rules and regulations of academic supervision. Mina said, "My supervisor did nothing for me. It was just a routine visit so that he could fill out the supervision forms and let the department know that he has visited me." In addition, Bayar stated:

The supervision is just a routine [formality], therefore, neither the supervisors nor the department pay a lot of attention to it. They do not deal with it as an essential part of the practicum. Supervisors do not know what they are supposed to do. I think the department should give supervisors clear instructions and guidelines about their duties when they visit a student.

The analysis of the data indicated that the supervisors' role in the practicum was not well defined by the EFL teacher preparation program. The participants' experiences with their supervisors revealed a kind of miscommunication between them. In addition, there was no meaningful communication between supervisors and cooperating teachers. Student teachers believed that each supervisor had his/her own particular set of rules for the practicum. They argued that the teacher education programs should have a set of standard rules of supervision to be followed by all the supervisors.

Site Document Findings:

All EFL teacher education programs in Kurdistan consist of eight semesters. Student teachers need to pass a practicum course in order to graduate. They take this course in the last year of their pre-service preparation. The practicum has two parts of observation and practice teaching. In the observation part of the course, student teachers observe an EFL teacher for a period of 50 days in a school of their choice. After this part is completed, student teachers are required to teach a class of EFL for 40 days in a school of their choice. Student teachers are then evaluated and graded by the cooperating teachers and supervisors.

The study found that the main reason behind the supervisors' limited time was the large number of the student teachers and the small number of the faculty members. Each faculty member usually supervises 10 student teachers during the practice teaching. Therefore, supervisors often had to travel between different schools in the same day and had little time to communicate with the student teachers and cooperating teachers. 


\subsection{The Role of the Cooperating Teachers}

Interview Findings:

Most of the participants did not value the role of the cooperating teachers they had worked with during their practicum. They described their cooperating teachers as unhelpful, unsupportive and irresponsible toward the student teachers. The study found that the participants expected support and productive feedback from their cooperating teachers, but they were often disappointed after they began their practice teaching. Sana said, "My cooperating teacher was not really cooperative." Bayar had the same opinion:

To be honest, when I began my practice teaching, I was scared. However, I was certain that my cooperating teacher would be there to help me. This idea of his support and help comforted me. In the first lecture, he came to the class and introduced me to the students and I did not see him again until the last day of the practicum when he signed my exit papers.

The participants argued that the cooperating teachers did not know their roles and responsibilities. Mina stated:

This was strange that the cooperating teachers did not know anything about their responsibilities. Our EFL education program had not instructed them about their duties during the teaching practice. I expected my cooperating teacher to observe me during the practicum and give me instructions to improve my teaching, but he did not. I asked him about this once and he said that no one told him to observe me.

The participants believed that it is the duty of the EFL education programs to give cooperating teachers detailed instructions about observing and helping student teachers. However, some of the participants argued that the cooperating teachers are not awarded for the extra work they do as a cooperating teacher, therefore, they do not take it seriously.

The study also revealed that the cooperating teachers used the student teachers as substitutes during the practicum. Fifteen of the participants complained that their cooperating teachers left them in the classroom with the children. Hamid said, "My mentor used me as a substitute teacher. He left me alone in the classroom with 40 kids and I was scared to death. I did not know what to do." The participants asserted that cooperating teachers were meant to be supporting to the student teachers during the practicum, but they were not. Mina said:

I do not know exactly the role of the cooperating teachers in the practicum and their responsibilities towards the student teachers and supervisors. Nevertheless, I simply expected my cooperating teacher to observe me in the class and support me. Unfortunately, it was not as I expected. I never saw him again during the practicum. I heard from his students that he took a vacation for 40 days.

Site Document Findings:

According to the manual of instructions for cooperating teachers, cooperating teachers do the mentoring of practice teaching voluntarily. They do not receive any compensation or benefits for the time and effort 
they put on the process of practicum. Furthermore, the analysis of the EFL teacher preparation curriculum and other related documents showed that the cooperating teachers do not receive any structured preparation or instructions about their roles and responsibilities as a cooperating teacher.

To sum up, the study found that most of the participants were not satisfied with the way they were treated by their cooperating teachers. The majority of the participants argued that the cooperating teachers were looking for this chance so that they could use the student teachers as substitutes and relax themselves. Furthermore, most of the participants believed that the cooperating teachers did not know their roles and responsibilities because they had not been instructed by their schools or by the EFL teacher education program.

\subsection{The Relationship between Supervisors and Cooperating Teachers}

The analysis that emerged from the data of the surveys, interviews, and site documents indicated that there was no coordination between the cooperating teachers and the supervisors.

Interview Findings:

Most of the participants could not find a meaningful relationship between their supervisors and cooperating teachers. The EFL teachers argued that supervisors and cooperating teachers must work with each other and exchange information on the student teachers' progress during the practicum. Matin said, "I think it was strange that my supervisor did not talk to my cooperating teacher when she visited me. I thought they should had talked about how I was doing." Milad stated:

Well, I think to make the practicum as fruitful as possible there should be a meaningful relationship among the student teachers, cooperating teachers, and supervisors. Cooperating teachers can inform the supervisors of student teachers' progress in the classroom. I think this will help us become better teachers.

The interviewees discussed that to integrate the knowledge of teaching to the act of teaching; they need to meet with supervisors and cooperating teachers on a regular basis. However, they argued that the cooperating teachers and supervisors never met and never exchanged any opinions during the practicum. Therefore, due to lack of communication between the parties who are involve, the practicum remained a formality in which the student teachers' duty was pleasing the supervisors and cooperating teachers in order to get a good grade.

The participants believed that there is a problem within the system where the schools and universities do not coordinate on such an important part of the student teachers' preparation. They argued that the roles of the cooperating teachers and supervisors are not defined, and they do not know how to treat student teachers and each other. Mina stated:

We could see that there was a lack of communication between cooperating teachers and supervisors. My supervisor had to visit four students in different parts of the city and he did not have enough time to talk to me. My cooperating teacher told me that he could not talk to my supervisor because the supervisor rushed out of the school after he did the observation. 
The participants thought that part of the problem goes back to the EFL teacher preparation program itself. They discussed that there are no defined and detailed standards of supervision designed by the program to help the supervisors and cooperating teachers know their duties and responsibilities. Furthermore, the supervisors and cooperating teachers are not trained to communicate with each other, and to observe and assess student teachers.

Site Document Findings:

After careful examination of the manual of instructions for cooperating teachers and supervisors in the EFL teacher education program under study, the researcher could not find any sections concerning the relationship between cooperating teachers and supervisors during the practicum.

\subsection{Supervisory Feedback}

Interview Findings:

The participants described the feedback they received from their supervisors and cooperating teachers as superficial, very brief, judgmental and unhelpful. Most of the participants argued that getting good feedback from their supervisors could have improved their teaching style, but it was not as they thought. Mina described the feedback she got from her supervisor as artificial. She said:

If the goal of practicum is to help student teachers practice their teaching and improve, they need more meaningful feedback from the mentors and supervisors. I am sorry to say that most of the feedback I received from my supervisor was superficial and useless.

Other participants believed that they got destructive feedback from their supervisors and they felt humiliated. For example, Amin said, "My supervisor told me that I will not be a good teacher. This destroyed my dream of becoming a teacher." The same thing happened to a few other participants. Armeen stated:

Supervisors are supposed to emphasize on the strong points of the student teachers and encourage them to correct and improve their weak points. My supervisor did exactly the contrary. He made a hill of my mistakes and did not really mention the good parts of my teaching. I think he did not help me.

The student teachers' interviews also revealed that the feedback they received from their supervisors was not detailed and comprehensive. Matin believed that the feedback he received from his supervisor was brief and unhelpful. He said:

Supervisors are supposed to help us find our weak points and give us detailed feedback so that we can improve ourselves. My supervisor evaluated my forty-five minutes of teaching in three lines he wrote in my lesson plan notebook. It was very general things on how well I managed the classroom. There were no specific details about my weak and strong points. I wish he could give me some advice on how to correct my students when they do a mistake. This was one of my biggest problems during the practice teaching and my supervisor never gave me a hint. 
Furthermore, the study found the authoritarian figure of the supervisors had a negative impact on the practicum. Most of the participants related this to the general "authority of knowledge" figure of the supervisors they have in their minds. The student teachers argued that they could not talk to their supervisors about their daily problems in the classroom frankly. Mina stated:

Well, it was not easy to talk to my supervisor about the problems I faced in the class. I was afraid these could affect my grades. Therefore, I just listened to my advisor and replied with yes to all his comments. In addition, I thought he knew everything about teaching and whatever he said must be correct.

\subsection{Observation}

Site Document Findings:

The program's manual for practicum states that observation is the first phase of the practicum in the EFL teacher education program. Student teachers are required to observe an experienced EFL teacher in the classroom of their choice for 45 minutes per day for 50 days. During the observation, they have special forms designed for this purpose that they are required to fill out. During this time, student teachers visit their universities once a week and discuss their observation experiences with their fellow student teachers and supervisors. However, the EFL programs' instructions for observation did not specify the detailed duties of the supervisors and cooperating teachers. In the observation section of the practicum manual, it is stated that the student teachers will observe an experienced EFL teacher of their choice in a school close to their neighborhood. It is also stated that the supervisors will visit the student teachers two times during the observation. The observation section did not include anything about the role and duties of the cooperating teachers.

Interview Findings:

Most of the participants described their observation experience as short and useless. They believed that they should have spent more time inside the classroom to become familiar with all the aspects of teaching. Mina stated:

The observation was very short. I believe it will be more beneficial if the student teachers have the chance to observe actual teachers teaching in real classrooms for the whole year or at least one semester. In this way, we can be familiar with all the aspects of teaching from the very beginning. I remember when I went to observe my cooperating teacher, it was near the end of the academic year, so I could not see the way he planned his lessons.

In addition to being short, the participants believed that the observation was not useful because they did not talk to the cooperating teachers or supervisors about what happened inside the classroom often. The participants believed that there should have been conferences among student teachers, cooperating teachers, and supervisors so that they get good constructive feedback. Bayar stated:

During the observation, I asked myself many questions about the way things were done inside the classroom. Why did the teacher do this? Why he did not correct the student when she made a mistake? Why the teacher did not explain the grammar? And many other similar 
questions. Nevertheless, there was no one to answer those questions. We had meetings in the university once every week, but we could not get all the answers in one short meeting.

The participants argued that the cooperating teachers were not usually available to answer their questions. Furthermore, in the weekly meetings they had in the university with their supervisors, there was not enough time to discuss what happened in the class during the last week. Therefore, the conferences were not productive or helpful.

However, a few participants argued that they learned many good things about teaching in real classrooms during their observations. They believed that they could identify many good techniques in their cooperating teachers' teaching that they could apply in their own classrooms. Matin said:

My cooperating teacher was a very experienced and excellent teacher. During the fifty days of the observation, I learned many good things from her teaching style. I filled my notebook with the very good techniques that she used to warm up her students, ask questions, and teach new vocabulary and pronunciation. I wish I could become a good teacher like her.

Drawing on the analysis of the EFL program's instructions and the participants' interviews, the study found that the cooperating teachers are chosen either by the student teachers themselves or by availability; and the quality of the cooperating teachers is not taken into consideration by the EFL teacher education program. Therefore, the experiences of the student teachers during observations can be very different. Some of them, like Matin, happen to observe good experienced teachers whom they benefit from and some others, like Bayar, encounter careless teachers whom the student teachers do not value.

\subsection{Time Limitation}

Interview Findings:

Most of the participants said that the period of their practice teaching was short. They believed that 40 days was not enough for practicing their teaching. Amin said, "There is much to learn about teaching and I think 40 days is not sufficient." In addition, Nergez noted:

I wish I had much more chance to practice my teaching. Our practice teaching was very short, about 40 days, and we did not have enough time to practice all the aspects of our teaching capabilities. I wish I had enough time to practice different teaching styles or different methods of assessment and their results on the learning process.

Site Document Findings:

The EFL program's manual for practicum has a section for practice teaching. There are two things mentioned in this section: 1) The student teachers will practice their teaching in a school of their choice that is close to their neighborhood for 40 school days and 2) the supervisors will visit the student teachers for two times during the practice teaching period. There are no more details given on the number of classes they should teach in one week or anything about cooperating teachers and their qualifications.

To conclude, the data analyzed from the surveys and interviews show that most of the participants were not satisfied with the role of their supervisors and cooperating teachers during the two phases of 
observation and practice teaching. Furthermore, most of them believed that the 50 days of observation and the 40 days of practice teaching was short. Feedback that were provided by the cooperating teachers and supervisors to student teachers during the practicum proved to be a big issue. Most of the participants were not satisfied with the feedback and described it as judgmental and unconstructive for their teaching.

\section{Discussion and Conclusion}

Research on field experience and practice show that student teachers who had observation and practice teaching experiences early in their programs performed better (Darling-Hamond \& Chung, 2002; Ingersol et al., 2007; Kee, 2012). EFL teachers in Kurdistan argued that they were not involved in any clinical experience until late in their programs, so that they did not have enough chance to see what it is to be a teacher. The analysis of the EFL program revealed that the practicum consisted of two parts, observation and practice teaching, and student teachers take this course in the last year of their pre-service preparation. In the observation part of the course, student teachers observe an EFL teacher for a period of 50 days in a school of their choice. After this part is completed, student teachers are required to teach an EFL class for 40 days in a school of their choice. Student teachers are then evaluated and graded by the cooperating teachers and supervisors. Most of them described their field experiences as insufficient and impractical. Kosar, an experienced EFL teacher in a high school in Hawler said, "Our student teaching experience was a real waste of time. We were left alone in a classroom full of children. There were no mentors and our faculty supervisors came to the class only one time."

Many participants said that they faced the disconnected experiences of the university and school. Hajar said "University and school are two different worlds. Our field experience was fragmented and was not supervised by experienced practitioners. So, we were not sure if what we were doing in the class was right or not." Darling-Hamond and Bransford (2005) stated, "Field work has often been divorced from coursework, inadequately designed, and placements have often failed to reflect standards for good teaching" (p. 454).

Drawing on the perspective of EFL teachers, this analysis suggests that the practicum was an unsuccessful experience of their pre-service preparation. The participants believed that during their practicum, they largely thought about pleasing their cooperating teachers and supervisors so that they could pass the course and graduate. The hierarchical value system of the Kurdish society, in which authority and respect are given to teachers, plays an important role in the way supervisors and student teachers communicate. Therefore, supervisors usually dominate the conversation and little chance is given to the student teachers to talk about their opinions and concerns. Supervisors usually expect student teachers to accept their advice as a prescription and preferred methodology.

Structural issues in the designing of the practicum proved to be one of the fundamental problems in the EFL teacher education programs in Kurdistan. Sofi-Karim (2015) found that the practicum period is too short, is poorly designed, and is poorly followed up by the faculty supervisors and the cooperating teachers. The researcher could not find detailed manuals or catalogues designed specifically for the student teachers, supervisors, and cooperating teachers to set the guidelines of the practicum and precisely define the responsibilities of the three parties. Student teachers argued that they did not know exactly what they were supposed to do as a practicing teacher. Similarly, findings revealed that the supervisors and cooperation teachers had the same problem. They did not know their responsibilities in the process of practicum. 
The lack of sufficient support and feedback from supervisors and cooperating teachers in the process of practicum was one of the main concerns of the EFL teachers. The participants described the practicum as a failure because they believed that they never received enough constructive feedback from their supervisors and cooperating teachers. He (2009) stated, "Without adequate communication between mentors and pre-service teachers regarding teaching expectations and beliefs, pre-service teachers leave the teacher education programs ill-prepared to negotiate potential conflict between their beliefs and reality of teaching, leading to dissonance and resistance to adaptation" (p. 264). In a similar study done by Payant and Murphy (2012), the importance of teamwork among student teachers, cooperating teachers, and faculty supervisors is one of the major findings. Collaboration among the three parties involved in the practicum, supervisors-cooperating teachers-student teachers, was missing in the EFL teacher education program under study.

On another level, the findings of the study indicated that there are serious structural issues in the designing of the field experience or practicum. The participants complained about the impracticality and shortness of the field experience during their pre-service preparation. They argued that the 40 days period of the practice teaching was short. Furthermore, they were not satisfied about the feedback they received from their supervisors and cooperating teachers and described their feedback as artificial, brief, and judgmental.

Practice teaching needs to be longer and supervised and mentored by expert teachers and faculty members. In-service teachers need to receive regular training to update their content and pedagogy knowledge. To prepare quality EFL teachers, the teacher education programs need to collaborate with schools to understand the real needs of the students and the schooling system. Moreover, these programs need to update their curriculum and pay more attention to the practice teaching. EFL teachers' voices are marginalized and neglected in the Kurdistan's education system. The curriculum is imposed on them and they have no say over its content. Teachers need to be consulted and trained properly over any changes that are to be made in the curriculum.

The findings of this study can be used for future planning in many areas but primarily in field of preservice EFL teacher preparation programs. The findings can be useful for the evaluation and designing of a new curriculum that can help prepare effective EFL teachers. Furthermore, this study can be used for designing a practical practicum that enforces the learning experience of the student teachers and helps them improve their teaching abilities.

\section{References}

Canh, L. V. (2014). Great expectations: The TESOL practicum as a professional learning experience. TESOL Journal, 5(2), 199-224.

Creswell, J. W. (2007). Qualitative inquiry and research design: Choosing among five approaches $\left(2^{\text {nd }}\right.$ ed.). Thousand Oaks, CA: Sage.

Darling-Hammond, L., Chung, R., \& Frelow, F. (2002). Variation in teacher preparation: How well do different pathways prepare teachers to teach. Journal of Teacher Education, 53(4), 286-302. Retrieved from http://jte.sagepub.com/content/ 53/4/286 ull.pdf+html

Darling-Hammond, L., \& Bransford, J. (2005). Preparing teachers for a changing world: What teachers should learn and be able to do. San Francisco, CA: Jossey-Bass. 
Farrell, T. S. C. (2007). Failing the practicum: Narrowing the gap between expectations and reality with reflective practice. TESOL Quarterly, 41, 193-201. doi:10.1002/j.1545-7249. 2007.tb00049.x

Farrell, T. S. C. (2008b). "Here's the book, go and teach the class": EFL practicum support. RELC Journal, 39, 226-241. doi:10.1177/0033688208092186

Flowerdew, J. (1999). The practicum in L2 teacher education: A Hong Kong case study. TESOL Quarterly, 33(1), 141-145.

Freeman, D. (1990). Intervening in practice teaching. In J.C. Richards \& D. Nunan (Eds.), Second language teacher education (pp. 103-17). Cambridge: Cambridge University Press.

He, Y. (2009). Strength- based mentoring in pre- service teacher education: A literature review. Mentoring \& Tutoring: Partnership in Learning, 17(3), 263-275.

Ingersoll, R. M., Gang, D., Meilu, S., Lai, K. C., Fujita, H., Kim, E, \& Boonyananta, S. (2007). A comparative study of teacher preparation and qualifications in six nations. The Consortium for Policy Research in Education, 1-117. Retrieved from http://www.eric.ed.gov/PDFS/ED498318.pdf

Kee, A. N. (2012). Feelings of preparedness among alternative certified teachers: What is the role of program features? Colleges for Teacher Education, 63(1), 23-38. Retrieved from http://jte.sagepub.com/content/63/1/23.full.pdf+html

Ochieng'Ong'ondo, C., \& Borg, S. (2011). "We teach plastic lesson to please them": The influence of supervision on the practice of English language student teachers in Kenya. Language Teaching Research, 15, 509-528. doi:10.1177/1362168811412881

Merriam, S., \& Tisdell, E. (2016). Qualitative research: A guide to design and implementation. San Francisco, CA: Jossey-Bass Inc Pub.

Patton, M. Q. (2015). Qualitative research and evaluation methods ( $4^{\text {th }} \mathrm{ed}$.). Thousand Oaks, CA: Sage.

Payant, C., \& Murphy, J. (2012). Cooperating teachers' roles and responsibilities in a MATESOL practicum. TESL Canada Journal, 29(2), 1-23.

RAND.KRG (2009). Basic school education system and secondary school education system. Council of Ministers. Erbil: MOE.

Richards, J. C. (1996). Teachers' maxims in language teaching. TESOL Quarterly, 30, 281-296.

Sofi-Karim, M. (2015). English language teaching in the Kurdistan region of Iraq (Order No.1595485). Available from ProQuest Dissertations \& Theses Global. (1709346177).

Stoynoff, S. (1999). The TESOL practicum: An integrated model in the U.S. TESOL Quarterly,33, 145151.

Vernez, G., Culbertson, S., \& Constant, L. (2014). Strategic priorities for improving access to quality education in the Kurdistan Region-Iraq. Retrieved January 26 2015, from http://www.rand.org/content/dam/rand/pubs/monographs/MG1100/MG1140-

1/RAND_MG1140-1.pdf Retrieved from http://0-search.proquest.com.library.uark.edu/ docview/1709346177? accountid=8361 